\title{
Diversifikasi Pengolahan Produk Cookies Eeg Roll Dengan Penambahan Tepung Ikan Teri
}

\section{Diversification Of Eeg Roll Cookies Processing With Subtitation Baby Fish Flour}

\author{
Ika Junianingsih" ${ }^{1)^{*}}$, Ismi jasila1), dan Lovi sandra1) \\ 1)Program Studi Pengolahan Hasil Perikanan, Fakultas Sains dan Teknologi, Universitas Ibrahimy, \\ Sukorejo, Situbondo
}

*Penulis Korespondensi : email: ikajunia05@yahoo.co.id

(Diterima September 2021/Disetujui Oktober 2021)

\begin{abstract}
Anchovy is a food of animal origin which is a source of protein and rich in calcium. Fish meal for basic food ingredients is still very rarely used compared to fish meal for feed (livestock) so it is necessary to make efforts to utilize this calcium-rich fish meal for various types of food products. The addition of anchovy flour in the manufacture of egg cookies or egg roll products to create healthy snacks or snack foods, has good nutrition needed by the body and is delicious to consume between main meals in the day. This research was conducted aimed at; 1) Knowing the egg roll processing process with the addition of anchovy flour, and 2) Knowing the formulation of the use of anchovy flour in egg roll processing. The stages of the research were carried out through 4 stages of processing; 1) Preparation of tools and selection of good raw materials, in order to produce quality egg rolls 2) Stage of making anchovy flour using the electric oven method. 3) The stage of processing egg roll dough by mixing all the raw materials step by step 4) The final stage, baking the dough using an egg roll mold. The results showed that the addition of anchovy flour with the formula 30:70 to the basic egg roll dough resulted in a dough texture that was not easily brittle and crumbled when forming/rolling the dough. Produces a crunchy and savory taste with a yellowishbrown appearance without a disturbing fishy tasty. The nutritional composition of egg roll with the addition of anchovy flour showed an average protein value of 60gr, calcium 2,381 $\mathrm{mg}$, phosphorus $1,225 \mathrm{mg}$, vitamin A $297 \mathrm{Sl}$, and energy $277 \mathrm{kcal}$.
\end{abstract}

Keywords: Anchovy flour, Egg roll, Diversification of processing

\section{ABSTRAK}

Ikan teri adalah bahan makanan asal hewani yang merupakan sumber protein dan kaya akan kalsium. Tepung ikan untuk bahan dasar pangan masih sangat jarang pemanfaatannya dibandingkan tepung ikan untuk bahan pakan (ternak) sehingga perlu dilakukan upaya untuk memanfaatkan tepung ikan yang kaya akan kalsium ini untuk berbagai jenis produk pangan. Penambahan tepung ikan teri pada pembuatan produk cookies telur atau egg roll untuk menciptakan makanan ringan atau snack food yang sehat, memiliki nutrisi baik yang dibutuhkan oleh tubuh serta enak dikonsumsi di antara waktu makan utama dalam sehari-hari. Penelitian ini dilakukan bertujuan untuk; 1) Mengetahui proses pengolahan egg roll dengan penambahan tepung ikan teri, dan 2) Mengetahui formulasi penggunaan tepung ikan teri pada pengolahan egg roll. Tahapan penelitian dilakukan melalui 4 tahapan pengolahan; 1) Tahap persiapan alat dan pemilihan bahan baku yang baik, agar menghasilkan egg roll yang berkualitas 2) Tahap pembuatan tepung ikan teri dengan metode pengovenan listrik. 3) Tahap pengolahan adonan egg roll dengan mencampur semua bahan baku step by step 4) Tahap akhir, pemanggangan adonan menggunakan cetakan egg roll. Hasil penelitian menunjukkan penambahan tepung ikan teri dengan formula 30:70 pada adonan dasar egg roll menghasilkan tekstur adonan tidak mudah rapuh dan hancur saat pembetukan/penggulungan adonan. Menghasilkan citarasa renyah dan gurih dengan penampakan coklat kekuningan tanpa bau amis yang mengganggu. Komposisi gizi

To Cite this Paper: Junianingsih, I., Jasila, I., Sandra, L., 2021. Diversifikasi Pengolahan Produk Cookies Eeg Roll Dengan Penambahan Tepung Ikan Teri. Samakia: Jurnal IImu Perikanan, 12 (2): 139-146.

Journal Homepage: https://journal.ibrahimy.ac.id/index.php/JSAPI 
egg roll dengan penambahan tepung ikan teri menunjukkan rataan nilai protein $60 \mathrm{gr}$, kalsium 2.381 $\mathrm{mg}$, fosfor $1.225 \mathrm{mg}$, vitamin A $297 \mathrm{SI}$, dan energy $277 \mathrm{kkal}$.

Kata Kunci: Tepung ikan teri, Egg roll, Diversifikasi pengolahan

\section{PENDAHULUAN}

Potensi perikanan laut Indonesia di perkirakan kurang lebih 6.6 jt ton pertahun. Salah satu jenis ikan yang banyak ditemukan diperairan Indonesia yaitu jenis ikan teri. Ikan teri merupakan bahan makanan asal hewani yang mengandung nilai gizi cukup tinggi, sehingga bermanfaat untuk pertumbuhan tubuh. Ikan teri merupakan ikan hasil laut yang dapat diolah menjadi berbagai macam olahan makanan yang memiliki nilai gizi tinggi serta memiliki harga jual yang ekonomis ( Heri, 2019). Ikan teri merupakan salah satu sumber kalsium terbaik untuk mencegah pengeroposan tulang sebab kalsium pada ikan teri lebih tahan dan tidak mudah larut dalam air. Kandungan gizi teri segar meliputi energi $77 \mathrm{kkal}$; protein $16 \mathrm{gr}$; lemak $1.0 \mathrm{gr}$; kalsium 500 mg; phosfor $500 \mathrm{mg}$; besi $1.0 \mathrm{mg}$; Vit A; dan Vit B $0.1 \mathrm{mg}$ (Asmoro dkk, 2018). Jenis-jenis ikan teri yang terdapat di Indonesia adalah ikan teri nasi (Stolephorus commersonii), teri gelagah (Stolephorus Indicus) dan teri jengki (Stolephorus Insularis). Dari ketiga jenis ikan teri tersebut, yang popular dan lebih diminati oleh masyarakat ialah ikan teri nasi atau lebih dikenal sebagai teri medan sebab memiliki warna putih dan aroma yang khas. Biasanya diolah menjadi rempeyek teri atau dibuat sambal teri. Sifat lain yang menguntungkan dari jenis ikan teri nasi tersebut dapat diolah atau diawetkan menjadi bermacam-macam hasil olahan sesuai dengan citarasa dan kesukaan konsumen. Salah satunya dapat dimanfaatkan menjadi tepung ikan sebagai bahan campuran pada pengolahan produk cookies eeg roll. Penggunaan tepung ikan teri diharapkan dapat mensubsitusi penggunaan telur dan susu pada olahan produk cookies egg roll. Eeg roll merupakan adonan yang terbuat dari telur dan tepung terigu dengan teknik pengolahan dipanggang menggunakan cetakkan egg roll kemudian digulung sehingga berbentuk pipa (Permata, 2018). Egg roll adalah makanan ringan (snack) yang berasal dari Asia Timur, yang dikonsumsi diantara waktu makan utama dalam sehari. Makanan ringan/cemilan yang sehat merupakan cemilan yang tidak hanya enak dalam segi citarasa akan tetapi juga memiliki komposisi gizi baik yang dibutuhkan oleh tubuh, seperti kandungan protein dan kalsium.

Tepung ikan teri nasi memiliki kandungan kalsium yang cukup tinggi apabila dibandingkan dengan kalsium yang terdapat pada susu sapi berdasarkan hasil penelitian Taufik (2017) yakni kandungan kalsium pada ikan teri nasi sebesar $330.10 \mathrm{mg} / 100 \mathrm{gr}$ ikan dan kalsium yang terdapat pada susu sapi sebesar $106.32 \mathrm{mg} / 100 \mathrm{gr}$ susu. Penggunaan tepung ikan teri sebagai sumber kalsium juga dilakukan oleh Heri (2019) pada penelitian pengolahan kue bawang yang menunjukkan hasil lebih diminati oleh masyarakat. Potensi penggunaan tepung ikan teri mendukung untuk terus dikembangkan menjadi berbagai produk olahan pangan. Penelitian yang berkaitan dengan pemanfaatan tepung ikan teri menjadi bahan dasar pembuatan cookies egg roll belum pernah dilakukan. Oleh karena itu, penelitian ini dilakukan untuk mempelajari dan menganalisa mengenai penambahan tepung ikan teri pada pengolahan egg roll terhadap kandungan gizi, citarasa, aroma, dan tekstur produk egg roll, sehingga diharapkan dapat menjadi makanan ringan yang lebih sehat dikonsumsi dan diminati oleh masyarakat.

\section{MATERI DAN METODE}

\section{Waktu dan Tempat Penelitian}

Lokasi penelitian dilakukan dilaboratotrium Teknologi Hasil Perikanan, Fakultas Sains dan Teknologi, Universitas Ibrahimy, Sukorejo-Situbondo, Jawa Timur. Penelitian ini dilakukan selama 1 bulan mulai Januari - Februari 2021

\section{Alat dan Bahan Penelitian}

Alat yang digunakan dalam penelitian ini adalah bowl, mixer, spatula, oven listrik, pemanggang egg roll, dan sendok-garpu. Alat untuk analisis kadar air, kadar abu, dan kadar kalsium antara lain botol timbang, oven, desikator, timbangan analitik, kompor listrik, tabor pengabuan, dan penjepit, crusibel, muffle furnance, erlenmeyer, kertas saring, gelas ukur, pipet tetes, statif, dan buret. Alat yang digunakan untuk daya terima berupa form organoleptik, alat tulis, piring kecil, dan plastik.

To Cite this Paper: Junianingsih, I., Jasila, I., Sandra, L., 2021. Diversifikasi Pengolahan Produk Cookies Eeg Roll Dengan Penambahan Tepung Ikan Teri. Samakia: Jurnal IImu Perikanan, 12 (2): 139-146.

Journal Homepage: https://journal.ibrahimy.ac.id/index.php/JSAPI 
Bahan yang digunakan dalam penelitian ini adalah tepung beras/terigu, tepung maizena/tapioka/kanji, tepung ikan teri, garam, telur, gula, margarine, cake emulsifier (ovalet), baking powder, susu cair dan vanilla. Bahan yang digunakan untuk uji kadar air dan kadar abu adalah sampel egg roll ikan teri. Bahan-bahan yang digunakan untuk uji kadar kalsium adalah egg roll, $\mathrm{HNO} 3, \mathrm{Mr}-\mathrm{BCG} 2, \mathrm{NH} 4 \mathrm{OH}, \mathrm{HNO}$, asam oksalat, ammonium oksalat, $\mathrm{H} 3 \mathrm{SO} 4$, dan KMNO4.

\section{Tahapan penilitian}

Penelitian dilakukan melalui 4 tahapan pengolahan; 1) Tahap persiapan alat dan pemilihan bahan baku yang baik, agar menghasilkan egg roll yang berkualitas 2) Tahap pembuatan tepung ikan teri dengan metode pengovenan listrik. 3) Tahap pengolahan adonan egg roll dengan mencampur semua bahan dasar step by step, dan 4) Tahap akhir, pemanggangan adonan menggunakan cetakan egg roll

\section{Teknik Pengumpulan Data}

Beberapa metode pengumpulan data pada penelitian kualitatif, yaitu:

\section{Data Primer}

Merupakan data yang diperoleh sebagai data utama, melalui pengumpulan data secara purposive sampling tentang bahan baku ikan teri, proses pengolahan tepung ikan teri, proses pengolahan egg roll, komposisi kimia produk, dan karakteristik sifat fungsional egg roll dengan penambahan tepung ikan teri (organoleptik). Sumber data primer didapatkan melalui wawancara (random sampling) Untuk pengumpulan data organoleptik dari masyarakat, hasil pengujian Laboratorium Fakultas Sains dan Teknologi Universitas Ibrahimy Sukorejo Situbondo, dan hasil perhitungan data.

\section{Data Sekunder}

Merupakan data yang diperoleh sebagai pendukung data primer, berupa letak geografis wilayah Situbondo, data statistik Pemerintah Daerah Kabupaten Situbondo, data statistik potensi pengolahan ikan teri dari Dinas terkait

Sumber data sekunder adalah Studi Literatur tentang penelitian yang sejenis, penelitian terdahulu, dokumen pendukung dari Dinas terkait (BPS Situbondo, DKP Situbondo, dan Pemda Situbondo).

\section{HASIL DAN PEMBAHASAN}

\section{Persiapan Bahan Baku}

Dalam proses pengolahan tepung ikan teri, bahan baku merupakan bagian yang memiliki peranan penting dalam keseluruhan pengolahan sehingga perlu mendapat perhatian lebih, karena sifat bahan - bahan tersebut akan mempengaruhi baik tidaknya hasil akhir dari pengolahan egg roll. Ikan yang dijadikan sebagai tolak ukur pada uji organoleptik adalah kenampakan fisik, bau, rasa, warna dan teksturnya. Ikan yang digunakan ialah ikan teri bermutu baik yaitu rupa dan warna: utuh, putih kebiruan dan terang: daging: kenyal dan berserat halus: bau/aroma: Amis ikan segar dan tidak busuk: rasa: netral agak manis. Untuk mempertahankan mutu ikan teri nasi, bahan baku harus cepat diolah, apabila terpaksa harus menunggu, maka ikan teri nasi harus disimpan dengan air dingin (es) dengan suhu $0{ }^{\circ} \mathrm{C}$ sampai $5{ }^{\circ} \mathrm{C}$, memperhatikan salinitas dan juga higenis (Fatmawati, 2019).

To Cite this Paper: Junianingsih, I., Jasila, I., Sandra, L., 2021. Diversifikasi Pengolahan Produk Cookies Eeg Roll Dengan Penambahan Tepung Ikan Teri. Samakia: Jurnal IImu Perikanan, 12 (2): 139-146. 


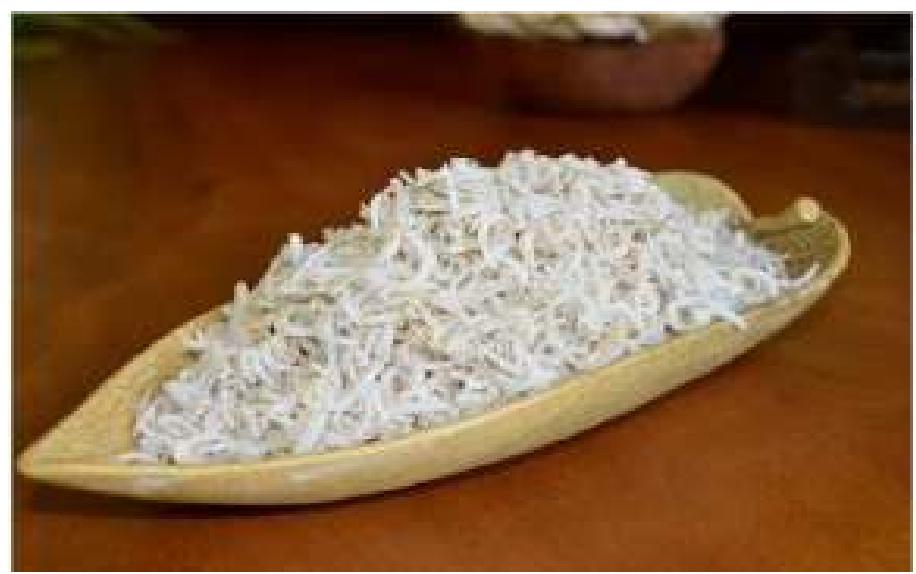

Gambar 1. Ikan Teri Nasi Segar

Pengadaan bahan baku teri segar diperoleh dari hasil tangkapan nelayan setempat yang biasanya mudah di dapatkan di tempat PPI Jangkar, Kabupaten Situbondo. Ikan teri segar yang baru diperoleh dari nelayan segera ditimbang untuk mengetahui berat awal bahan baku, kemudian dicuci bersih dengan air mengalir untuk disiapkan ke proses selanjutnya. Untuk mengetahui komposisi kimia awal ikan teri segar dilakukan analisa proksimat terhadap kandungan gizi ikan teri segar. Pada uji proksimat yang dijadikan tolak ukur uji adalah kadar protein, karbohidrat, lemak, kalsium, dan vitamin. Berikut tabel komposisi kimia ikan teri segar disajikan pada tabel dibawah ini:

Tabel 1. Komposisi Kimia Ikan Teri Segar

\begin{tabular}{lc}
\hline Kandungan gizi per $\mathbf{1 0 0}$ gram & Jumlah \\
\hline Energy (kkal) & 77 \\
Protein (gr) & 16 \\
Lemak (gr) & 1.0 \\
Karbohidrat (gr) & 0 \\
Kalsium (mg) & 500 \\
Fosfor(mg) & 500 \\
Besi(mg) & 1.0 \\
Vitamin A (SI) & 150 \\
Vitamin B1(mg) & 0.05 \\
Air (g) & 80 \\
\hline
\end{tabular}

Sumber: analisa proksimat primer

\section{Pengolahan Tepung Ikan Teri}

Sortasi atau pemilihan ikan teri sangatlah penting untuk menentukan kualitas teri yang baik. Memilih ikan teri yang baik yakni masih berwarna putih segar, berisi dan kering, apabila ada teri yang sudah sedikit empuk atau berair pisahkan karena akan mengurangi kualitas tepung ikan teri. Ikan teri yang digunakan pada penelitian ini ialah jenis ikan teri nasi (Stolephorus commersonii) berasal dari tangkapan nelayan setempat. Setelah ikan teri selesai disortasi dilakukan penimbangan sebanyak 250 gram untuk menghasilkan tepung ikan teri sebanyak 100 gram

Pada proses pembuatan tepung ikan teri ada tahapan-tahapan yang harus dilakukan yaitu pemilihan bahan baku ikan, pencucian, penirisan, pengeringan, pemanggangan, penggilingan dengan food prosessor, dan yang terakhir pengayakan. Setiap tahapan proses pengolahan tepung ikan teri harus dilakukan sesuai dengan standart prosedur agar menghasilkan tepung ikan teri yang baik dan bermutu.

To Cite this Paper: Junianingsih, I., Jasila, I., Sandra, L., 2021. Diversifikasi Pengolahan Produk Cookies Eeg Roll Dengan Penambahan Tepung Ikan Teri. Samakia: Jurnal IImu Perikanan, 12 (2): 139-146. 


\section{Pencucian}

Pencucian dilakukan setelah ikan teri disortir dan ditimbang. Dalam tahap ini ikan teri dicuci menggunakan air mengalir dan setelahnya direndam selama 5 menit untuk mengangkat kotoran yang melekat pada ikan teri tersebut. Setelah direndam, kemudian ikan teri ditiriskan hingga tidak terlalu banyak air pada ikan teri.

\section{Penirisan}

Setelah ikan teri dicuci bersih lalu ikan teri diletakkan di wadah berjaring agar air yang ada pada ikan teri pada saat pencucian bisa menetes keluar. Proses penirisan dilakukan selama 15 menit untuk memastikan bahwa air cucian ikan teri habis sempurna. Sehingga dapat diproses ke tahap selanjutnya.

\section{Pemanggangan oven listrik}

Ikan teri nasi yang sudah kering pada tahap sebelumnya kemudian disusun diatas loyang yang sudah disiapkan untuk dipanggang pada oven listrik dengan suhu oven sebesar $120^{\circ} \mathrm{C}$ selama 4 jam untuk kapasitas ikan teri sebanyak $250 \mathrm{gr}$. Kelebihan dari membuat tepung ikan teri nasi dengan menggunakan oven listrik adalah warna tepung ikan teri yang dihasilkan lebih baik berwarna putih serta lebih praktis akan tetapi kelemahan dari tidak ekonomisnya penggunaan listrik pada pembuatannya. Pemanggangan dengan oven listrik membutuhkan waktu yang relatif lebih lama bila dibandingkan menggunakan oven gas (2,5 jam) maupun disangrai (1,5 jam). Proses pemanggangan bertujuan untuk menghilangkan kadar air ikan teri dan mendapatkan ikan teri nasi yang kering sempurna sehingga lebih mudah untuk ditepungkan pada poses selanjutnya.

\section{Penggilingan dengan food prosessor}

Ikan teri yang sudah dipanggang selanjutnya didinginkan selama 10 menit sebelum digiling. Pada penilitan ini penggilingan ikan teri nasi yang dipanggang menggunakan food processor hingga ikan teri halus seperti tepung kasar. Proses penggilingan dilakukan setelah ikan teri dingin terlebih dahulu dimaksudkan untuk mencegah terjadinya pemanasan berlanjut yang dapat menyebabkan over cooking atau burning.

\section{Pengayakan}

Hasil gilingan tepung ikan teri nasi yang masih kasar selanjutnya diayak menggunakan ayakan 100 mesh kemudian diletakkan di wadah kedap udara untuk menghindari kontaminasi. Untuk $250 \mathrm{gr}$ ikan teri nasi segar akan menghasilkan $100 \mathrm{gr}$ tepung ikan teri halus dan $30 \mathrm{gr}$ tepung ikan teri kasar ( butiran yang tidak halus). Hasil dari tahapan akhir inilah yang disebut tepung ikan teri nasi sebagai bahan dasar yang akan digunakan pada pembuatan adonan egg roll.

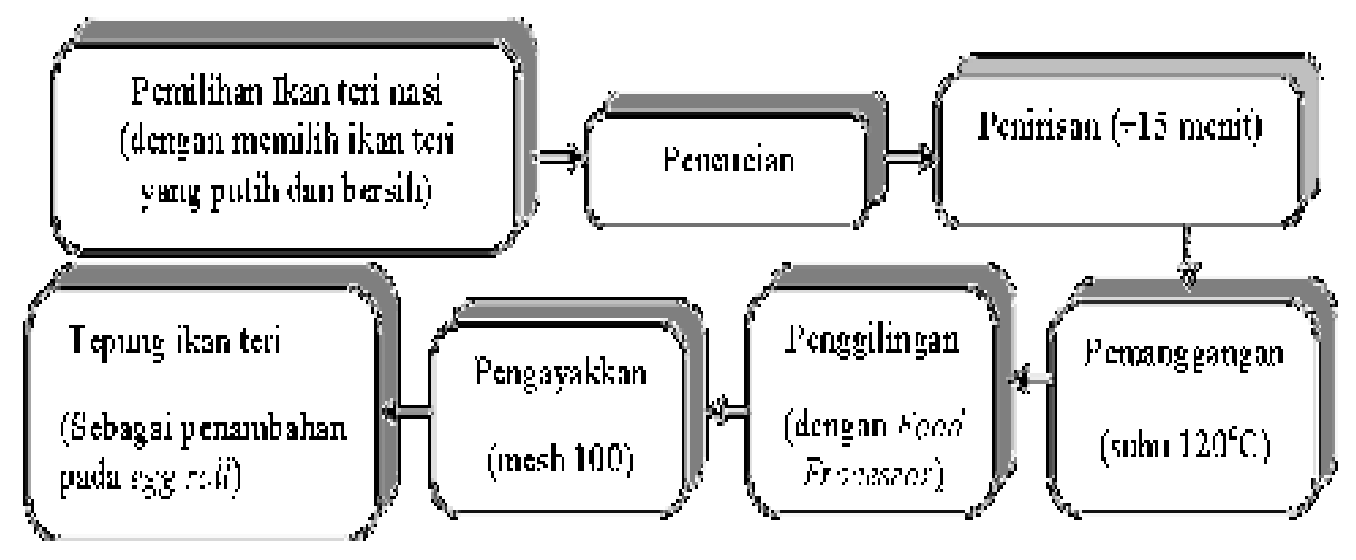

Gambar 2. Alur Pengolahan Tepung Ikan Teri Nasi

\section{Proses Pengolahan Egg Roll}

Egg roll merupakan cookies telur berbentuk roll terbuat dari telur dan tepung terigu dengan teknik pengolahan dipanggang menggunakan cetakkan egg roll kemudian digulung sehingga berbentuk pipa. Ciri khas egg roll bercita rasa telur panggang, memiliki tekstur yang renyah, serta memiliki warna kuning kecoklatan. Bahan-bahan yang digunakan dalam pembuatan egg roll pada penelitian

To Cite this Paper: Junianingsih, I., Jasila, I., Sandra, L., 2021. Diversifikasi Pengolahan Produk Cookies Eeg Roll Dengan Penambahan Tepung Ikan Teri. Samakia: Jurnal IImu Perikanan, 12 (2): 139-146. 
ini terdiri dari dua bagian yaitu bahan-bahan utama yang berfungsi sebagi pengikat yakni: tepung terigu, telur, susu cair serta bahan pembantu yang berfungsi sebagai pelembut yakni: gula, margarine, cake emulsifier (SP), dan baking powder. Penambahan tepung ikan teri nasi pada penelitian ini menggunakan perbandingan 30:70 dari formula dasar pembuatan egg roll. Berikut tabel formula dasar egg roll disajikan dibawah ini:

\section{Formula Dasar Egg Roll}

Tabel 2. Formula Dasar Egg Roll

\begin{tabular}{|c|c|}
\hline Nama bahan & Jumlah (gram; ml) \\
\hline Tepung terigu : Tepung ikan teri & $70: 30$ \\
\hline Garam & 1 \\
\hline Gula Pasir & 75 \\
\hline Telur & 120 \\
\hline Susu cair & 100 \\
\hline Margarine & 25 \\
\hline Vanilla & 2 \\
\hline Cake emulsifier & 5 \\
\hline Baking powder & 2 \\
\hline
\end{tabular}

Langkah pertama pembuatan egg roll substitusi dengan tepung teri nasi adalah gula pasir, telur ayam, dan ovalet dikocok hingga mengembang kental, kemudian dicampur dengan tepung terigu, tepung tapioca, susu bubuk, dan vanili. Setelah adonan tercampur rata ditambahkan tepung teri nasi dengan perbandingan $30: 70 \%$. Adonan yang sudah tercampur rata ditambahkan margarin yang sudah dicairkan. Kemudian adonan dicetak menggunakan cetakan egg roll yang sudah panas dan diolesi sedikit minyak. Setelah agak kering, egg roll digulung menggunakan sumpit dan diangkat, kemudian dilepas dari sumpit Anggraini (2018) menjelaskan bahwa waktu yang dibutuhkan untuk membuat adonan sekitar 15-20 menit. Setelah adonan tercampur rata berikutnya diamkan adonan selama \pm 10 menit untuk memberikan waktu baking powder bekerja. Hal ini dilakukan untuk mempermudah saat penggulungan agar tekstur egg roll tidak mudah rapuh dan hancur

\section{Pencetakan Egg Roll}

Proses pemanggangan adonan dengan cetakkan egg roll dimulai terlebih dahulu memanaskan panggangan egg roll yang telah diolesi dengan mentega setelah itu tuang setengah sendok adonan lalu tutup pemanggang dan matangkan selama \pm 30 detik kemudian gulung egg roll yang telah matang berbentuk pipa dengan segera, sebab setelah egg roll matang menjadi dingin, maka egg roll akan rusak pada saat dibentuk rol/digulung. Terakhir, proses pengemasan egg roll dilakukan menggunakan wadah kedap udara (vakum) untuk menjaga kerenyahan egg roll. Diagram alur pengolahan egg roll disajikan pada gambar berikut:

To Cite this Paper: Junianingsih, I., Jasila, I., Sandra, L., 2021. Diversifikasi Pengolahan Produk Cookies Eeg Roll Dengan Penambahan Tepung Ikan Teri. Samakia: Jurnal IImu Perikanan, 12 (2): 139-146. 


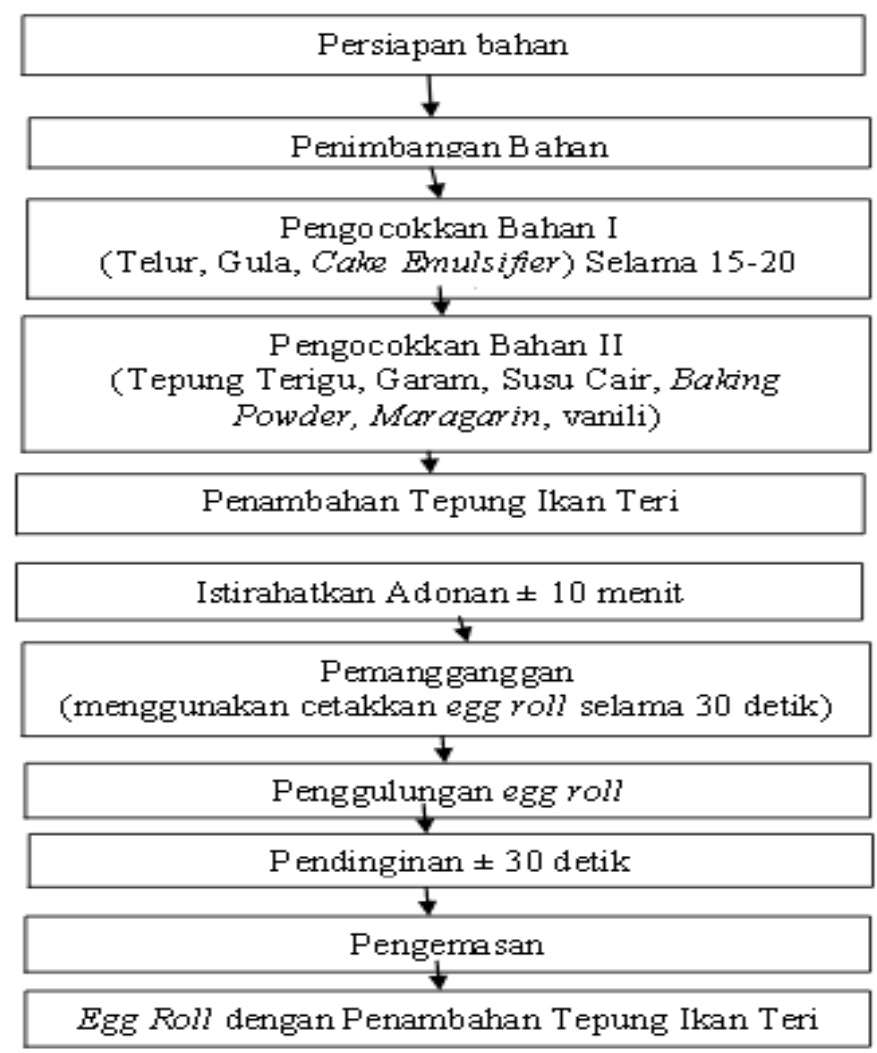

Gambar 3. Alur Pencetakan Egg Roll

Kriteria egg roll yang baik dapat dinilai dari hasil analisa laboratorium. Metode analisa laboratorium secara kimia untuk mengidentifikasi kandungan nutrisi suatu bahan makanan/pakan dikenal sebagai uji proksimat. Pengujian laboratorium tersebut untuk mengetahui kadar air, kadar abu, protein, lemak dan serat. Protein pada egg roll ikan teri mengandung sejumlah asam amino esensial, yakni isoleusin, leusin, lisin dan valin, juga mengandung asam amino non esensial, yakni asam glutamat dan asam aspartat, masing-masing kadarnya mencapai 1.439 dan $966 \mathrm{mg}$. Kandungan nutrisi pada egg roll ikan teri dapat dilihat dari tabel dibawah ini:

Tabel 3. Komposisi Gizi Egg Roll Dengan Tepung Ikan Teri

\begin{tabular}{lc}
\hline \multicolumn{1}{c}{ Kandungan Gizi per $\mathbf{1 0 0}$ gram } & Egg Roll dengan Tepung teri ikan \\
\hline Energy (kkal) & 277 \\
Protein (gr) & 60.0 \\
Lemak (gr) & 2.33 \\
Karbohidrat (gr) & 1.8 \\
Kalsium (mg) & 2.381 \\
Fosfor(mg) & 1.225 \\
Besi(mg) & 3.0 \\
Vitamin A (SI) & 297 \\
Vitamin B1(mg) & 0.1 \\
Air (g) & 15.0 \\
\hline
\end{tabular}

Sumber:Analisa proksimat primer

To Cite this Paper: Junianingsih, I., Jasila, I., Sandra, L., 2021. Diversifikasi Pengolahan Produk Cookies Eeg Roll Dengan Penambahan Tepung Ikan Teri. Samakia: Jurnal IImu Perikanan, 12 (2): 139-146. 


\section{KESIMPULAN}

Proses pembuatan egg roll dengan substitusi tepung teri nasi adalah gula pasir, telur ayam, dan ovalet dikocok hingga mengembang kental, kemudian dicampur dengan tepung terigu, tepung tapioca, susu bubuk, dan vanili. Setelah adonan tercampur rata ditambahkan tepung teri nasi dengan perbandingan 30:70\%. Adonan yang sudah tercampur rata ditambahkan margarin yang sudah dicairkan. Kemudian adonan dicetak menggunakan cetakan egg roll yang sudah panas dan diolesi sedikit minyak. Setelah agak kering, egg roll digulung menggunakan sumpit dan diangkat, kemudian dilepas dari sumpit

Penambahan tepung ikan teri nasi pada pembuatan egg roll mampu meningkatkan citarasa dan nilai gizi produk snack food tersebut, sehingga produk tersebut dapat diterima dengan baik oleh masyarakat. Komposisi gizi egg roll dengan penambahan tepung ikan teri menunjukkan rataan nilai protein 60gr, kalsium $2.381 \mathrm{mg}$, fosfor $1.225 \mathrm{mg}$, vitamin A $297 \mathrm{SI}$, dan energy 277 kkal. Peningkatan citarasa egg roll dengan penambahan tepung ikan teri menghasilkan egg roll yang lebih renyah, gurih, tidak mudah rapuh, dan beraroma tidak amis.

\section{DAFTAR PUSTAKA}

Anggraini, S. 2018. Pengaruh Substitusi Tepung Pisang Kepok Putih pada Egg Roll terhadap Kadar Vitamin C dan Daya Terima. Tesis. Universitas Muhammadiyah Surakarta. Surakarta.

Astawan, D. 2018. Kadar Pati Resisten, Kalsium, dan Zat Besi serta Daya Terima Kue Kering Tepung Pisang Kepok dengan Penambahan Tepung Teri Kering Tawar. Fakultas Kedokteran Universitas Diponegoro. Semarang

Erwin. 2019. Pengaruh Substitusi Tepung Pisang pada Pembuatan Brownies terhadap Sifat Kimia dan Penerimaan Organoleptik. Balai Riset dan Standarisasi Industri Padang. Padang

Fatmawati. 2019. Kajian Resiko Usaha Pengolahan Ikan Teri Di Desa Pagurawan, Kecamatan Medan Deras, Kabupaten Batu Bara, Provinsi Sumetera Utara.Jurnal Agresip ISSN: 14128837 Vol. 11

Heri.2019. Pengolahan Kue Bawang Dengan Penambahan Tepung Ikan Teri.Skripsi. Fakultas Tehnik. Universitas Negeri Jakarta. http//repository.unj.ac.id

Indrajaya. 2020. Penggunaan Daging dan Tulang Ikan Bandeng (Chanos chanos) pada Stik Ikan Sebagai Makanan Ringan Berkalsium dan Berprotein Tinggi. Jurnal Teknologi Hasil Perikanan Vol. IX No. 2

Permata, M. A. dan Hendrikus N.P. 2018. Sifat Kimia dan Organoleptik Cookies dengan Penambahan Tepung Pisang Kepok Putih. Universitas Katolik Widya Karya. Malang

Rahmawati. 2018. Substitusi Tepung Pisang Kepok Putih Dalam Pembuatan Egg Roll Terhadap Kadar Kalsium Dan Daya Terima Produk. Tesis. Fakultas Kesehatan. Universitas Muhammadiyah Surakarta

Taufik, A. W. putra. 2017. Perbedaan kandungan Kalsium Pada Ikan Teri Nasi (Stolephorus commersonii) Dengan Susu sapi Lokal Di kabupaten Jember. Skripsi. Fakultas Teknologi Pertanian. Universitas Jember. http//repository.unej.ac.id

To Cite this Paper: Junianingsih, I., Jasila, I., Sandra, L., 2021. Diversifikasi Pengolahan Produk Cookies Eeg Roll Dengan Penambahan Tepung Ikan Teri. Samakia: Jurnal IImu Perikanan, 12 (2): 139-146. 